\title{
Międzynarodowa mobilność edukacyjna jako determinanta rozwoju osobistego i zawodowego studentów
}

\section{KEYWORDS}

internationalisation, labour market, educational mobility, Erasmus + programme, graduates' skills, employability

\begin{abstract}
Magdalena Zapotoczna, Międzynarodowa mobilność edukacyjna jako determinanta rozwoju osobistego i zawodowego studentów [Educational mobility as a determinant of students' personal and professional development]. Kultura - Społeczeństwo - Edukacja nr 2(20) 2021, Poznań 2021, pp. 217-230, Adam Mickiewicz University Press. ISSN 2300-0422, ISSN (Online) 2719-2717. DOI $10.14746 / \mathrm{kse} .2021 .20 .13$
\end{abstract}

The aim of the article is to analyze the extent, to which the participation of students in learning mobility projects on the example of the Erasmus + programme influences the improvement of their individual skills desired from the perspective of the labour market. The text begins with an introduction that outlines the background to the considerations undertaken. Next, the historical context of learning mobility in Europe and the process of internationalization of universities are presented as one of the consequences of the globalizing labour market. In the following part of the article we characterized the best known European programme promoting academic mobility Erasmus +. The end of the article contains a review of the research on the competences of beneficiaries of learning mobility projects, supported by statistical data, and an attempt to draw a link between participation in student exchange and the chances of finding a satisfactory employment after graduation. The analysis shows that graduates with foreign mobility experience develop a number of characteristics and skills, that increase their employability and career opportunities.

* ORCID: https://orcid.org/0000-0001-7109-9464. 


\section{Wprowadzenie}

W następstwie dokonujących się przemian społeczno-kulturowych i gospodarczych rynek pracy podlega dynamicznym przeobrażeniom strukturalnym i organizacyjnym. Znamienne jest zjawisko destandaryzacji pracy charakteryzujące się nowymi formami zatrudnienia, liberalizacją czasu i miejsca pracy oraz swobodnym przepływem kapitału, wiedzy i siły roboczej (Stiglitz, 2007: 9). Adaptacja do nowej rzeczywistości wymusza na pracownikach gotowość do permanentnej aktualizacji wiedzy i umiejętności, a zatem elastycznego dostosowania kompetencji i kwalifikacji do potrzeb rynku pracy oraz wymagań pracodawców (Sloman, 2001: 184-185). Rezultatem tych zmian jest zapotrzebowanie na edukację przygotowującą absolwentów szkół do przekraczania osobistych i zewnętrznych granic oraz do funkcjonowania w świecie nieprzewidywalnym, różnorodnym i niestabilnym.

Sytuacji tej nie ułatwia fakt, iż wzrost liczby studentów na przestrzeni ostatnich dwudziestu lat przekłada się na istnienie dużej konkurencji, a co za tym idzie trudności ze znalezieniem pracy przez osoby rozpoczynające karierę zawodową. Najczęściej wskazywanymi barierami są brak doświadczenia zawodowego oraz niedopasowanie umiejętności (skill mismatch), czyli rozdźwięk pomiędzy jakością formalnego wykształcenia a jego rzeczywistą wartością na rynku pracy (Quintini, 2011: 17-21). Różnice między poziomem kompetencji (kwalifikacji) posiadanym przez absolwentów a pożądanym przez potencjalnych pracodawców wynikają z braku konkretnych umiejętności zawodowych i przede wszystkim społecznych $\mathrm{w}$ takim zakresie, jak: praca $\mathrm{w}$ grupie, relacje interpersonalne, samodzielność i przedsiębiorczość (Kwiatkowski, 2013: 21).

Pilna potrzeba poprawy jakości i adekwatności kompetencji absolwentów kieruje uwagę na aktualny poziom bezrobocia młodych ludzi w krajach Unii Europejskiej. Badania Eurostatu (2019) wskazują, że w pierwszym kwartale 2019 roku odsetek osób w wieku 15-24 lata pozostających bez pracy wyniósł 14,6\%. Wprawdzie sytuacja zawodowa młodych ludzi ulega stopniowej poprawie, jednak w dalszym ciągu liczba osób doświadczających trudności ze znalezieniem pracy plasuje się w Europie na poziomie czterech milionów. Ponadto ok. 40\% europejskich pracodawców wskazuje na problemy w znalezieniu kandydatów dysponujących odpowiednimi umiejętnościami, głównie w zakresie znajomości języka obcego, kompetencji interpersonalnych czy adaptacji do nowych sytuacji (European Commission, 2018: 157).

Stworzenie modelu kompetencyjnego, tj. względnie stałego i uniwersalnego zestawu kompetencji, jest bardzo trudne, a wręcz niemożliwe. Niemniej jednak nie słabną wysiłki dotyczące prognozowania ogólnych wytycznych dotyczących kategorii kompetencji niezbędnych do rozwoju osobistego oraz integracji spo- 
łecznej i zatrudnienia. Wyniki tychże badań stają się podstawą do formułowania rekomendacji dla decydentów w obszarze polityki oświatowej, począwszy od kształcenia ogólnego i zawodowego, na szkolnictwie wyższym kończąc. Inicjatywy polityczne zarówno na poziomie krajowym, jak i europejskim, potwierdzają znaczenie oceny i jakości szkolnictwa wyższego, którego celem jest poprawa szans zatrudnienia absolwentów posiadających umiejętność dostosowania zawodowego (Council of the European Union, 2012a).

Jednym z obszarów wspierania studentów przez uczelnie wyższe w pozyskaniu kompetencji, ułatwiającym im wejście na rynek pracy jest promocja zagranicznej mobilności, czyli wyjazdów na studia, praktyki i kursy intensywne. Jak wskazują opracowania eksperckie, ma ona znaczący wpływ na dalsze losy życiowe i determinuje ścieżki rozwoju zawodowego młodych ludzi (Kelo, Teichler, Wächter, 2006; Teichler, Ferencz, Wächter, 2011; Pachocki, 2018). Wyniki raportów potwierdzają potencjał projektów mobilności w rozwoju osobistym i zawodowym studentów, wskazując na powiązanie doświadczeń nabywanych podczas studiów ze zwiększonymi szansami na znalezienie zatrudnienia po zakończeniu edukacji. Udział w praktykach lub realizacja części programu studiów za granicą wykracza często poza ramy formalnej edukacji i sprzyja większej otwartości, samodzielności i elastyczności beneficjentów (Komisja Europejska, 2014). Prócz poznania obcej kultury pobyt za granicą skutkuje zwiększeniem świadomości kulturowej i dostrzeżeniem potrzeby uczenia się języków obcych.

Celem niniejszego artykułu ${ }^{1}$ jest wykazanie związku mobilności zagranicznej studentów - beneficjentów programu Erasmus - z poprawą ich indywidualnych umiejętności i szans na rynku pracy. W tekście zaprezentowano zestawienie najnowszych danych z europejskich wyników badań prowadzonych wśród studentów i absolwentów mających doświadczenie mobilności. Podstawowymi metodami badawczymi są przegląd piśmiennictwa i analiza danych statystycznych, jak również dostępnych sprawozdań na temat związku mobilności studenckiej z rozwojem kompetencji. Autorka odwołuje się do wyników badań przeprowadzonych przez ekspertów Komisji Europejskiej pn. Badanie wplywu programu Erasmus. Wpływ mobilności na zdobywanie umiejętności i szanse zatrudnienia studentów oraz na umiędzynarodowienie instytucji szkolnictwa wyższego (2014) oraz raportów z badań Fundacji Rozwoju Systemu Edukacji Mobilność kluczem do kariery? Raport z badania losów uczestników zagranicznych staży i praktyk zawodowych (Pacho-

${ }^{1}$ Niniejszy artykuł ukazał się w języku angielskim: M. Zapotoczna (2019), Educational Mobility as a Determinant of Students' Personal and Professional Development, [w:] M. Zapotoczna (red.), Towards the Internationalisation of Education and the Labour Market. The European Perspective, Torun, s. 85-99. 
cki, 2018) oraz Erasmus... i co dalej? Badanie losów edukacyjnych i zawodowych polskich studentów uczestniczących w projektach mobilności w programie Erasmus (Dąbrowska-Ręsiak, 2018). Źródło danych statystycznych stanowią sprawozdania i opracowania eksperckie na temat mobilności studentów, jak: Flash Eurobarometer, Eurodata Student Mobility in European Higher Education oraz Mapping Mobility in European Higher Education.

\section{Kontekst historyczny międzynarodowej mobilności studentów}

Mobilność edukacyjna w Europie ma długą i bogatą historię (Baron, 1993: 50-54). Okres przypadający na lata 1950-1970 określany jest jako benevolent laissez-faire (życzliwy leseferyzm), charakteryzujący się polityką otwartych drzwi dla studentów zagranicznych, którzy pochodzili głównie z kolonii francuskich i brytyjskich. Promowanie mobilności edukacyjnej stanowiło ważny element polityki zagranicznej Francji i Wielkiej Brytanii, wynikający z chęci utrzymania wpływów politycznych na skolonizowanych terenach, zacieśnienia stosunków międzynarodowych oraz pozyskania przyszłych elit wśród absolwentów. Obraz ten przekształcił się w kolejnych dwóch dekadach. W latach 1970-1990 nastąpiła zmiana podejścia do mobilności studentów - z działań zorientowanych na pozyskanie studentów zagranicznych do promowania studiów za granicą. Początek lat 90. to czas upowszechniania idei mobilności edukacyjnej studentów, po roku 1992 rozszerzonej również o mobilność akademicką adresowaną do pracowników uczelni. W krajach Wspólnoty Europejskiej, a następnie Unii Europejskiej mobilność stała się istotą, a zarazem celem procesu unifikacji szkolnictwa wyższego.

Zdaniem Rahula Choudahy (2017: 1-8) w historii projektów wymiany studenckiej ostatnich dwóch dekad (1999-2019) wskazać można na istnienie tzw. fal międzynarodowej mobilności studenckiej (waves of international student mobility), na których atrakcyjność w poszczególnych okresach wpływ miały wydarzenia o charakterze globalnym. Pierwszy etap przypadający na lata 1999-2006 zdeterminowany był rozwojem technologii informacyjno-komunikacyjnych początku lat 90. XX wieku i zapotrzebowaniem na wysoko wykwalifikowanych pracowników w dziedzinie nauk ścisłych i technologii. Istotnym elementem budowania własnej doskonałości badawczej i prestiżu uczelni wyższych było przyciąganie i zatrzymanie utalentowanych studentów z zagranicy. Początkowo ze względu na bazę badawczą i możliwości finansowania krajem docelowym wielu studentów były Stany Zjednoczone. Jednakże ataki terrorystyczne z 11 września 2001 roku oraz zaostrzone wymagania wizowe spowodowały spadek atrakcyjności USA dla potencjal- 
nych stypendystów. W tym samym czasie proces boloński i konstytuowanie się Europejskiego Obszaru Szkolnictwa Wyższego spowodowały dynamiczny wzrost liczby studentów zagranicznych w krajach europejskich.

Tłem wydarzeń dla drugiej fali mobilności (2007-2013) był światowy kryzys gospodarczy, którego szczyt przypadł na lata 2008-2009. Jednym ze skutków recesji były redukcje budżetu w szkolnictwie wyższym. Paradoksalnie zainteresowanie uczelni rekrutacją studentów zagranicznych wzrosło, przede wszystkim ze względu na znacznie wyższe dochody związane z przyjęciem studentów zagranicznych w uczelni w porównaniu ze środkami przeznaczanymi na studentów krajowych. Znamienny dla drugiej fali mobilności był wzrost gotowości instytucji szkolnictwa wyższego do przyjmowania znacznie większej liczby studentów zagranicznych przy jednoczesnym braku wsparcia finansowego i ograniczonych zasobach instytucjonalnych. Proces rekrutacji z wysoce selektywnego w pierwszej fazie mobilności (rekrutacja utalentowanych studentów z zagranicy) zmienił się w bardziej masowy w czasie drugiej fali (rekrutacja studentów zagranicznych).

Trzecia fala mobilności (2014-2020) uwarunkowana jest ważnymi wydarzeniami o charakterze globalnym, jak kryzys migracyjny w Europie (2015), amerykańskie wybory prezydenckie (2016), decyzja Wielkiej Brytanii o opuszczeniu struktur Unii Europejskiej (2017) oraz spowolnienie gospodarcze chińskiej gospodarki (2018). Wydarzenia te miały negatywny wpływ na politykę imigracyjną i nastroje społeczne dotyczące kwestii bezpieczeństwa w poszczególnych krajach wspólnoty. Czynniki demograficzne, jak starzenie się populacji Europy i gospodarcze związane z podniesieniem konkurencyjności krajów europejskich, spowodowały zmianę polityki, gdyż to m.in. w studentach zagranicznych dostrzeżono potencjalną grupę pracowników przyszłości. W centrum zainteresowań władz oświatowych znalazło się podniesienie innowacyjności programów i warunków kształcenia na uczelniach wyższych, nawiązywanie nowych partnerstw strategicznych oraz rozwój e-learningu. Dla trzeciej fali mobilności charakterystyczna jest rywalizacja między krajami docelowymi spowodowana chęcią przyciągnięcia jak największej liczby studentów z zagranicy oraz sprostania ich oczekiwaniom dotyczącym możliwości rozwoju kariery i szans na zatrudnienie.

\section{Działania na rzecz umiędzynarodowienia szkolnictwa wyższego}

Wynikiem modernizacji sektora szkolnictwa wyższego ostatnich kilkunastu lat jest wzmocnienie umiędzynarodowienia systemów szkolnictwa wyższego, któ- 
rego wymierny efekt i największy potencjał stanowi mobilność studentów i naukowców. Choć wyjazdy zagraniczne są najwyraźniej obserwowalnymi cechami procesu internacjonalizacji, to nie stanowią jego jedynych wskaźników. Mając na uwadze potencjał projektów mobilności, uczelnie ukierunkowują swoje wysiłki na zacieśnianie współpracy międzynarodowej służącej konsolidacji europejskiego obszaru szkolnictwa wyższego (Martín, 2012).

Proces zmian, który rozpoczął się w 1999 roku, doprowadził do modernizacji i ujednolicenia systemów szkolnictwa wyższego w krajach Europy (The Bologna Declaration, 1999). Kontynuacją działań było opracowanie przez Radę Unii Europejskiej i Parlament Europejski pod koniec 2006 roku ramowych wytycznych określających nowe umiejętności i sposoby ich kształtowania w procesie uczenia się przez całe życie (Zalecenie Parlamentu Europejskiego i Rady, 2006). W przyjętym dokumencie podjęto próbę określenia wiadomości, zdolności i postaw, nazwanych kompetencjami kluczowymi, które umożliwią obywatelom efektywne funkcjonowanie w tworzącym się społeczeństwie opartym na wiedzy, a także sprzyjają samorealizacji jednostki, pomagają w procesie integracji społecznej oraz ułatwiają odnalezienie się na rynku pracy².

Po upływie dekady weryfikacja kompetencji kluczowych stała się ponownie przedmiotem prac Komisji Europejskiej. W 2016 roku przyjęto nowy program na rzecz umiejętności pn. New Skills Agenda for Europe, którego główną intencją było m.in. stworzenie narzędzi służących monitorowaniu rynku pracy i profilowaniu kwalifikacji absolwentów szkół po to, by zwiększać szanse młodych Europejczyków na zatrudnienie i w rezultacie podnieść konkurencyjność Europy (European Commission, 2016).

W najnowszej strategii Unii Europejskiej na rzecz młodzieży realizowanej w latach 2019-2027 za główny cel przyjęto podniesienie poziomu mobilności edukacyjnej, promowanie aktywnego uczestnictwa w życiu społecznym, poprawę dialogu międzykulturowego oraz wykorzystanie potencjału kultury do osiągnięcia postępu społecznego i gospodarczego w Europie (Resolution, 2019). W krajach wspólnoty europejskiej uruchomiono również szereg inicjatyw diagnozujących rynek pracy i podaż kompetencji, co umożliwia wskazanie obszarów niedopasowania umiejętności do potrzeb i wyzwań rynku pracy.

\footnotetext{
${ }^{2}$ Opracowanie zawiera listę następujących kompetencji kluczowych: kompetencje w zakresie rozumienia i tworzenia informacji, kompetencje w zakresie wielojęzyczności, kompetencje matematyczne oraz kompetencje w zakresie nauk przyrodniczych, technologii i inżynierii, kompetencje cyfrowe, kompetencje osobiste, społeczne i w zakresie umiejętności uczenia się, kompetencje obywatelskie, kompetencje w zakresie przedsiębiorczości, kompetencje w zakresie świadomości i ekspresji kulturalnej.
} 
Od momentu wejścia w życie Deklaracji Bolońskiej mobilność i umiędzynarodowienie stanowią kluczowy priorytet wspólnych celów krajów Unii Europejskiej w zakresie edukacji i szkolenia. Obecnie ważnym i szeroko dyskutowanym zjawiskiem jest internacjonalizacja szkolnictwa wyższego, która obejmuje szereg działań realizowanych na poziomie centralnym oraz na poziomie poszczególnych uczelni, co znajduje swoje odzwierciedlenie w strategiach ich rozwoju. Pierwsze próby zdefiniowania internacjonalizacji na poziomie instytucjonalnym zostały podjęte pod koniec lat 80. ubiegłego wieku. Odwołując się do jednej z najbardziej powszechnych definicji zaproponowanej przez Jane Knight (1994: 7; 2003: 2) w połowie lat 90., a rozszerzonej dekadę później, przyjmuje się, że internacjonalizacja to proces łączenia wymiaru międzynarodowego, międzykulturowego i globalnego z celem, funkcjami i sposobami funkcjonowania szkół wyższych.

Choć motywy internacjonalizacji uczelni wyższych są bardzo zróżnicowane, to zauważa się, że prócz wymiaru politycznego i społeczno-kulturowego ważne znaczenie mają czynniki ekonomiczne. Wyraźny wzrost tych uwarunkowań $\mathrm{w}$ ostatnich latach wynika $\mathrm{z}$ procesów globalizacji, jak również związany jest z oczekiwaniami pracodawców w zakresie znajomości przez absolwentów specyfiki rynku międzynarodowego. W ujęciu jednostkowym doświadczenie mobilności postrzegane jest przez zagranicznych studentów jako element osobistej strategii zwiększania własnej konkurencyjności na globalnym rynku pracy (Domański, 2017: 65). Z kolei w ujęciu instytucjonalnym odsetek zagranicznych studentów będących odbiorcami usług edukacyjnych stanowi istotne kryterium oceny poziomu dydaktycznego uczelni oraz wskaźnik różnego rodzaju rankingów uczelni wyższych (Perspektywy, 2019).

W 2009 roku w komunikacie wydanym przez ministrów europejskich odpowiedzialnych za szkolnictwo wyższe stwierdzono, że „mobilność studentów, początkujących naukowców i pracowników podnosi jakość programów i doskonałość w badaniach [oraz] wzmacnia akademickie i kulturowe umiędzynarodowienie europejskiego szkolnictwa wyższego" (Communiqué, 2009). Dalej zwrócono także uwagę na znaczenie mobilności dla „rozwoju osobistego i szans na zatrudnienie, które sprzyja poszanowaniu różnorodności i umiejętności radzenia sobie z innymi kulturami. Zachęca do pluralizmu językowego, wspierając w ten sposób wielojęzyczną tradycję Europejskiego Obszaru Szkolnictwa Wyższego oraz zwiększa współpracę i konkurencję między instytucjami szkolnictwa wyższego" (Communiqué, 2009). W konkluzji wypowiedzi ministrów wyrażono również nadzieję, że w 2020 roku co najmniej 20\% absolwentów uczelni wyższych w Europie będzie miało za sobą doświadczenie udziału w studiach lub praktykach za granicą. 


\section{Program Erasmus}

Fundamentalne znaczenie dla poprawy jakości i innowacyjności kształcenia mają działania ukierunkowane na wspieranie mobilności studentów i kształtowanie pożądanych z perspektywy rynku pracy kompetencji. Sztandarowym programem Unii Europejskiej w dziedzinie edukacji na poziomie szkolnictwa wyższego jest Erasmus, poprzez który ustanowione zostały formalne ramy współpracy uczelni wyższych w krajach wspólnoty.

Oficjalnie został on przyjęty decyzją Rady Wspólnoty Europejskiej 15 czerwca 1987 roku, lecz geneza jego powołania jest długa, poprzedzona serią spotkań i dyskusji polityków oraz profesorów akademickich z różnych krajów. Fenomen programu Erasmus przyczynił się do stworzenia nowego pokolenia Europejczyków i został „zaprojektowany, aby przyczynić się do rozwoju Europy Ludzi, a tym samym będąc czymś więcej niż tylko inicjatywą akademicką, stał się skutecznym instrumentem politycznym kształtującym pokolenia europejskich studentów" (Feyen, Krzaklewska, 2013).

W historii istnienia programu Erasmus, czyli European Community Action Scheme for the Mobility of University Students, można wyróżnić cztery fazy. W latach 1987-1995 głównym celem programu Erasmus była wymiana studentów i kadry akademickiej, opracowywanie programów studiów na poziomie międzyuczelnianym i kursów intensywnych. W drugiej fazie (1995-2006) Erasmus stał się komponentem szerszego programu współpracy unijnej pod nazwą Socrates, ukierunkowanego na zawiązywanie współpracy dydaktycznej uczelni i umiędzynarodowienie studiów. W trzeciej fazie przypadającej na lata 2007-2013 Erasmus był częścią programu Lifelong Learning, w którym promowano koncepcję kształcenia przez całe życie i otwarcie się uczelni na potrzeby gospodarki. W tym okresie wprowadzono również nowe formy mobilności, jak praktyki zagraniczne dla studentów i wyjazdy szkoleniowe dla pracowników. W czwartej fazie programu (2014-2020) program funkcjonuje pod nazwą Erasmus + i stanowi kontynuację podjętych wcześniej działań.

Na lata 2021-2027 przyjęto nazwę Erasmus Programme oraz podwojono budżet edycji, który wyniesie 30 miliardów euro. Od czasu uruchomienia programu, czyli od ponad trzech dekad, w programie Erasmus udział wzięło blisko trzy i pół miliona studentów z całej Europy. Zainteresowanie wyjazdami zagranicznymi z jednej strony powiązać można z postępem w realizacji procesu bolońskiego i integracji europejskiej w obszarze szkolnictwa wyższego. Z drugiej zaś strony ze zwiększoną świadomością decydentów w dziedzinie edukacji i gospodarki dokonujących się przemian i potrzeby reagowania na nie. 


\section{Wpływ mobilności edukacyjnej na rozwój kompetencji studentów}

Raporty dotyczące wpływu mobilności edukacyjnej na rozwój osobisty i zawodowy beneficjentów programu Erasmus prowadzone są głównie pod auspicjami Komisji Europejskiej, narodowych agencji programu i sieci Eurydice. W analizach poświęconych mobilności edukacyjnej ważnymi obszarami eksponowanymi w badaniach są: kompetencje, dostosowanie zawodowe, zatrudnienie, przebieg kariery zawodowej, tożsamość i integracja europejska, życie prywatne beneficjentów. $\mathrm{W}$ artykule analizie poddano wybrane aspekty mobilności istotne z perspektywy rozwoju osobistego i zawodowego absolwentów.

$\mathrm{Z}$ badań prowadzonych w ramach Erasmus Impact Study wynika, że doświadczenie uzyskane za granicą sprzyja otwartości, samodzielności, elastyczności absolwentów oraz skutkuje poprawą znajomości języków obcych i umiejętności międzykulturowych (Komisja Europejska, 2014: 62). Podobnie autorzy badań Flash Eurobarometer - Youth on the move zgodni są co do kwestii, iż znajomość języków obcych, wzrost świadomości różnic kulturowych oraz lepsza zdolność adaptacji do nowych sytuacji stanowią trzy główne korzyści z wyjazdów zagranicznych wymieniane przez samych studentów (Gallup Organization, 2011: 36).

W badaniach Fundacji Rozwoju Systemu Edukacji respondenci studiujący lub odbywający praktykę za granicą podkreślali związek mobilności z ich rozwojem osobistym: zwiększenie umiejętności i kompetencji (82\%), samooceny i postrzegania siebie (81\%). Prawie dwie trzecie studentów pozytywnie oceniło wpływ wyjazdu na zagraniczne stypendium na ich dalsze losy zawodowe - zarówno rozwój, jak i plany dotyczące zatrudnienia (66\%) (Dąbrowska-Ręsiak, 2018: 34). Część respondentów zwróciła również uwagę na związek doświadczenia mobilności z ich sytuacją życiową (44\%) i wybór miejsca zamieszkania (36\%). Warto nadmienić, że na podstawie odpowiedzi respondentów zaobserwowano pewne różnice w korzyściach ze względu na typ realizowanej mobilności (studia lub praktyki za granicą). Znaczny odsetek beneficjentów, którzy uczestniczyli w praktykach w ramach programu Erasmus podkreślił wartość wyjazdu w rozwoju ich kariery zawodowej, zwiększenia szans na znalezienie zatrudnienia i ułatwienie podjęcia pracy po zakończeniu edukacji. Z kolei wyjazd na studia, zdaniem absolwentów, przyczynił się do ich ogólnego rozwoju osobistego - podniesienia kompetencji językowych i międzykulturowych, pogłębienia wiedzy oraz nawiązania relacji towarzyskich (Dąbrowska-Ręsiak, 2018: 34).

Zakrojone na szeroką skalę badania pod nazwą VALERA (Value of Erasmus Mobility) przeprowadzone przez zespół Olivera Brachta (2006: 208-210) wykazały, że studenci z doświadczeniem mobilności wykazują wyższą samoocenę kom- 
petencji miękkich, wśród których wymieniana jest świadomość międzykulturowa, adaptacyjność, elastyczność, innowacyjność, produktywność, motywacja, wytrwałość, umiejętność rozwiązywania problemów i zdolność do efektywnej pracy w zespole w porównaniu do studentów, którzy nie uczestniczyli w programach mobilności. Wszystkie te umiejętności i kompetencje są powiązane z gotowością do zatrudnienia (employability) rozumianą jako zestaw kluczowych kompetencji doskonalonych w procesie uczenia się (Yorke, 2006). W wielu raportach poświęconych mobilności stypendyści programu Erasmus wskazywali na pozytywny wpływ ich międzynarodowego doświadczenia w staraniach o pierwszą pracę. W opinii respondentów studia lub praktyki za granicą stanowiły istotny element ich curriculum vitae $\mathrm{w}$ staraniach o zatrudnienie wymagające znajomości języka obcego, wrażliwości na różnice kulturowe i umiejętności współpracy w zespole międzynarodowym (Teichler 2009: 99). Jako kandydaci zostali również lepiej ocenieni przez swoich pracodawców, co znajduje odzwierciedlenie choćby w badaniach Ulricha Teichlera (2017: 203).

Prócz badań adresowanych do beneficjentów projektów mobilności prowadzone są również analizy akcentujące perspektywę pracodawców. Jednym z przykładów jest opracowanie The Employability of Higher Education Graduates: The Employer's Perspective (Humburg, van der Velden, Verhagen, 2013). Celem analizy było poznanie potrzeb pracodawców i ich opinii na temat czynników warunkujących zdolności absolwentów do pracy. Jak wynika z danych, pracodawcy w pierwszej kolejności zwracali uwagę na zgodność kierunku studiów z profilem zawodowym oraz posiadane doświadczenie zawodowe absolwentów. Pracodawcy, biorąc na siebie odpowiedzialność za profesjonalne przygotowanie kandydatów w zakresie wiedzy i umiejętności specyficznych dla danego stanowiska, kierowali swoją uwagę w drugiej kolejności na umiejętności interpersonalne kandydatów, jak komunikacja i praca w zespole oraz zdolności planowania i organizacji pracy związane z elastycznością, innowacyjnością myślenia i postawą przedsiębiorczą.

Wyniki międzynarodowych badań losów absolwentów prowadzonych w ramach takich projektów, jak Cheers (w latach 1998-2000), Reflex (2005-2006) czy Trackit (2010-2012) wskazują, że znaczna część pracowników legitymujących się doświadczeniem mobilności za czasów studenckich dostrzega powiązanie między ich kompetencjami a powierzanymi im zadaniami zawodowymi. Tezę tę potwierdzają wyniki badań ankietowych przeprowadzone wśród pracodawców (Janson, Schomburg, Teichler, 2009: 74-75). Ponad dwa razy częściej absolwenci z doświadczeniem mobilności w porównaniu do absolwentów bez takiego doświadczenia wykonywali zadania wymagające znajomości kontekstu międzynarodowego, jak: posługiwanie się językiem obcym, kontakt ze współpracownikami lub klientami 
z innych krajów, nawiązywanie stosunków międzynarodowych, podróże służbowe za granicę lub czasowe oddelegowanie do innego kraju.

Badania przeprowadzone na zlecenie Komisji Europejskiej wskazały, że 64\% pracodawców uznało doświadczenie mobilności za istotny element wpływający na atrakcyjność potencjalnego pracownika i jego umiejętności dostosowania zawodowego zwiększający szanse na zatrudnienie (Komisja Europejska, 2014: 125). Ponadto istotną kwestią wynikającą $\mathrm{z}$ badań był poziom zatrudnialności absolwentów. W 2014 roku stopa bezrobocia wśród studentów mobilnych była o 21\% niższa niż wśród studentów, którzy nie mieli doświadczenia międzynarodowej wymiany. Prócz tego ryzyko długotrwałego bezrobocia po ukończeniu studiów było o połowę niższe niż wśród studentów niemobilnych (Komisja Europejska, 2014: 139). Ten aspekt mobilności okazał się równie ważny w kontekście samozatrudnienia, co znalazło swoje odzwierciedlenie w wynikach badań nad postawami przedsiębiorczymi absolwentów. Co dziesiąty beneficjent Erasmusa założył własną firmę, a jedna trzecia wszystkich mobilnych studentów nie wykluczała lub planowała podjęcie takiego przedsięwzięcia w przyszłości.

\section{Podsumowanie}

Formułowanie i wdrażanie skutecznych rozwiązań edukacyjnych i szkoleniowych stanowi ciągłe wyzwanie dla krajów wysoko rozwiniętych. Szybko zachodzące przemiany rynku pracy, prowadzące do powstania globalnego społeczeństwa wiedzy, generują nowe zadania dla systemu edukacji związane z potrzebą doskonalenia warunków wchodzenia na rynek pracy absolwentów szkół wyższych. Sprostanie temu wyzwaniu wymaga powiązania rozwoju umiejętności młodych ludzi z możliwościami uzyskania przez nich (międzynarodowego) doświadczenia jeszcze w czasie studiów, zaangażowania partnerów społecznych i interesariuszy zewnętrznych, a także systematycznego monitoringu rynku pracy.

Na poziomie uczelni wyższych państwa europejskie przy wsparciu instytucji europejskich intensyfikują swoje wysiłki zorientowane na zacieśnianie i dalszy rozwój współpracy międzynarodowej. Funkcjonujący od ponad 30 lat program Erasmus przyczynił się do zwiększenia oferty programowej w językach obcych, promocji mobilności akademickiej oraz wprowadzenia standardów podnoszących jakość kształcenia w uczelniach. W procesie umiędzynarodowienia i wymiernej konsolidacji europejskiego szkolnictwa wyższego mobilność odgrywa bardzo istotną rolę.

Zgodnie z założeniami programu Erasmus projekty mobilności studentów, czyli wyjazdy na studia, praktyki czy kursy intensywne, mają na celu podniesie- 
nie poziomu kluczowych kompetencji i umiejętności przydatnych na rynku pracy (European Commision, 2017: 28). Daje to szansę doskonalenia kompetencji miękkich, kompetencji językowych, obycia w środowisku odmiennym językowo i kulturowo oraz rozwoju osobistego. Udział w wymianie to też istotny element nauki samodzielności, zaradności i odpowiedzialności, wzmacniający samoocenę i pewność siebie beneficjentów projektu. Zdaniem Racheli Brooks i Johanny L. Waters (2011: 11) „istnieją ważne dowody na to, że przynajmniej w niektórych krajach kwalifikacje za granicą często prowadzą do znaczących korzyści na rynku pracy”. W istocie doświadczenie uzyskane za granicą jest pozytywnie oceniane w kontekście coraz bardziej konkurencyjnego rynku pracy. Dzięki realizacji części studiów lub praktyk w innym kraju studenci mogą doświadczyć różnych podejść do nauki i zawodu oraz poznać metody nauczania i szkolenia stosowane w odmiennych od rodzimego kontekstach edukacyjno-zawodowych.

Z terminem "mobilność" nieodłącznie wiążą się takie pojęcia, jak zmiana, rozwój, wyzwanie, odwaga do przekraczania granic, wyjście ze znanego schematu i poza własną strefę komfortu (OECD, 2017: 72). Wyniki badań wskazują, że partycypacja w wymianie międzynarodowej w ramach studiów czy praktyk zagranicznych jest ważnym doświadczeniem dla młodych ludzi, które ma istotny wpływ na ich dalsze losy życiowe i nierzadko determinuje ścieżki rozwoju zawodowego. Można zatem stwierdzić, że doświadczenie mobilności sprzyja nie tylko realizacji jednostkowych celów zawodowych studentów i kształtowaniu ich biografii życiowych, lecz służy także rozwojowi uczelni wyższych w wymiarze międzynarodowym i realnej konwergencji europejskiej.

\section{Bibliografia}

Baron B. (1993), The Politics of Academic Mobility in Western Europe, Higher Education Policy, 6(3), s. $50-54$.

Bracht O., Engel C., Janson K., Over A., Schomburg H., Teichler U. (2006), The Professional Value of Erasmus Mobility, Kassel, https://www.eurashe.eu/library/modernising-phe/mobility/professional/WG4\%20R\%20Professional\%20value\%20of\%20ERASMUS\%20mobility\%20Teichler. pdf, dostęp: 23.11.2020.

Brooks R., Waters J.L. (2011), Student Mobilities, Migration and the Internationalization of Higher Education, Hampshire.

Choudaha R. (2017), Three Waves of International Student Mobility (1999-2020), Studies in Higher Education, 42(5), s. 1-8.

Communiqué of the Conference of European Ministers Responsible for Higher Education, Leuven and Louvain-la-Neuve, 28-29 April 2009, https://europa.eu/rapid/press-release_IP-09-675_ en.htm, dostęp: 23.11.2020. 
Council of the European Union (2012a), Council Conclusions on the Employability of Graduates from Education and Training, Brussels, http://www.consilium.europa.eu/uedocs/cms_data/docs/ pressdata/en/educ/130142.pdf, dostęp: 23.11.2020.

Council of the European Union (2012b), Press Release: 3164th Council Meeting - Education, Youth, Culture and Sport, Brussels, https://www.consilium.europa.eu/uedocs/cms_data/docs/pressdata/en/educ/130177.pdf, dostęp: 23.11.2020.

Dąbrowska-Ręsiak J. (2018), Erasmus... i co dalej? Badanie losów edukacyjnych i zawodowych polskich studentów uczestniczących w projektach mobilności w programie Erasmus, Warszawa.

Domański T. (2017), Internacjonalizacja polskich uczelni wyższych, [w:] T. Domański, A. Stępień-Kuczyńska, A. Włodarska-Frykowska (red.), Internacjonalizacja polskich ośrodków politologicznych, Łódź, s. 63-80.

European Commission (2016), A New Skills Agenda for Europe. Working Together to Strengthen Human Capital, Employability and Competitiveness, Brussels.

European Commission (2017), Erasmus+ Programme Guide, version 2, https://ec.europa.eu/programmes/erasmus-plus/sites/erasmusplus2/files/erasmus-plus-programme-guide2_en.pdf, dostęp: 23.11.2020.

European Commission (2018), Employment and Social Developments in Europe, Annual Review 2018, https://ec.europa.eu/social/main.jsp?langId=en\&catId=89\&newsId=9150, dostęp: 23.11.2020.

Eurostat (2019), Euro Area Unemployment at 7.8\%, https://ec.europa.eu/eurostat/documents/ 2995521/9697394/3-01042019-BP-EN.pdf/899edf8c-529b-422a-acla-ce0fede29fa3, dostęp: 23.11.2020.

Feyen B., Krzaklewska E. (red.) (2013), The ERASMUS Phenomenon - Symbol of a New European Generation?, Frankfurt am Main.

Gallup Organization (2011), Youth on the Move. Analytical Report, Brussels, https://ec.europa.eu/ commfrontoffice/publicopinion/flash/fl_319b_en.pdf, dostęp: 23.11.2020.

Humburg M., van der Velden R., Verhagen A. (2013), The Employability of Higher Education Graduates: The Employer's Perspective, Brussels.

Janson K., Schomburg H., Teichler U. (2009), The Professional Value of ERASMUS Mobility, Bonn.

Kelo M., Teichler U., Wächter B. (red.) (2006), EURODATA - Student Mobility in European Higher Education, Bonn.

Knight J. (1994), Internationalization: Elements and Checkpoints, CBIE Research, 7, s. 1-14.

Knight J. (2003), Updating the Definition of Internationalization, International Higher Education, 33 , s. $2-3$.

Komisja Europejska (2014), Badanie wplywu programu Erasmus. Wplyw mobilności na zdobywanie umiejętności i szanse zatrudnienia studentów oraz na umiędzynarodowienie instytucji szkolnictwa wyższego, Luksemburg.

Kwiatkowski S.M. (2013), Kształcenie zawodowe w formach szkolnych - wyzwania edukacyjne i gospodarcze, Debata Edukacyjna, 6, s. 17-26.

Martín P.M. (2012), The European Union Tackling Youth Unemployment in Times of Crisis, Berlin, http://library.fes.de/pdffiles/id/ipa/09516.pdf, dostęp: 23.11.2020.

OECD (2017), In-Depth Analysis of the Labour Market Relevance and Outcomes of Higher Education Systems: Analytical Framework and Country Practices Report, Enhancing Higher Education System Performance, Paris, http://www.oecd.org/education/skills-beyond-school/LMRO\%20 Report.pdf, dostęp: 23.11.2020. 
Pachocki M. (2018), Mobilność kluczem do kariery? Raport z badania losów uczestników zagranicznych staży i praktyk zawodowych, Warszawa.

Perspektywy (2019), Ranking szkół wyższych, http://perspektywy.pl/RSW2019/tables/mrwzsalbft_ RSW/pdf/RSW-2019-ranking-uczelni-akademickich.pdf, dostęp: 23.11.2020.

Quintini, G. (2011), Over-Qualified or Under-Skilled: A Review of Existing Literature, OECD Social, Employment and Migration Working Papers, No. 121, OECD Publishing.

Resolution of the Council of the European Union and the Representatives of the Governments of the Member States meeting within the Council on a framework for European cooperation in the youth field (2019), The European Union Youth Strategy 2019-2027, https://eur-lex.europa.eu/ legal-content/EN/TXT/?uri=CELEX\%3A42018Y1218\%2801\%29, dostęp: 23.11.2020.

Sloman J. (2001), Podstawy ekonomii, Warszawa.

Stiglitz J.E. (2007), Globalizacja, Warszawa.

Teichler U. (2009), Internationalisation of Higher Education: European Experiences, Asia Pacific Education Review, 10(1), s. 93-106.

Teichler U. (2017), Internationalisation Trends in Higher Education and the Changing Role of International Student Mobility, Journal of International Mobility. International mobility: brain drain, brain gain?, 5(1), s. 177-216.

Teichler U., Ferencz I., Wächter B. (red.) (2011), Mapping Mobility in European Higher Education. Volume 1: Overview and Trends, Brussels.

The Bologna Declaration of 19 June 1999. Joint declaration of the European Ministers of Education, https://www.eurashe.eu/library/bologna_1999_bologna-declaration-pdf/, dostęp: 23.11.2020.

Yorke M. (2006), Employability in higher education: what it is - what it is not, The Higher Education Academy, York, https://www.qualityresearchinternational.com/esecttools/esectpubs/yorkeknightembedding.pdf, dostęp: 23.11.2020.

Zalecenie Parlamentu Europejskiego i Rady z dnia 18 grudnia 2006 r. w sprawie kompetencji kluczowych w procesie uczenia się przez całe życie, https://eur-lex.europa.eu/legal-content/PL/TXT/ PDF/?uri=CELEX:32006H0962\&from=EN, dostęp: 23.11.2020. 